country; I am in England, everywhere, and under any meridian." Only the "Ionl multitude" that chnoses by show he holds up to derision as "that numerous piece of monstrosity, which, taken asunder, seem men, and the reasonable creatures of God; but confused together, make but one great beast, and a monstrosity more prodigious than Hydra." He has a quirk sympathy with the sorrows of others, and, though a physician, his prayer is with the husbandman and for healthful seasons. No one has put more beautifully the feeling which each one of us has had at times about patients : "Let me be sick myself, if sometimes the malady of my patient be not a disease unto me; I desire rather to cure his infirmities th tn my own necessities; where I do him no good, methinks it is scarce honest gain; though I confess 'tis but the worthy salary of our well-intended endeavours."

He has seen many countries, and has studied their customs and politics. He is well versed in astronomy and botany. Fe hus run through all systems of philosophy but has found no rest in any. As death gives every fool gratis the knowledge which is won in this life with sweat and vexation, he counts it absurd to take pride in his achievements, though he understands six languages besides the patois of several provinces.

As a scientific man Browne does not take rank with many of his contemporaries. He had a keen power of observation, and in the Pseudodoxic and in his letters there is abundant evidience that he was an able naturalist. He was the first to observe and describe the peculiar substance known as adipo. cere, and there are in places shrewd flashes, anch as the suggestion that the virus of rabies may be mitigated by transmission from one animal to another. We miss in him the clear, dry light of science as revealed in the marvellous works of his contemporary, Harvey. Busy as a practical phystcian, he was an observer, not an experimenter to any extent, though ho umg-s: "Join sense unto reason and experiment unto geeculation, and 80 give life unto embryon truths and verities yet in their chaos." $\mathrm{He}$ had the higheat veneration for Farver. whose work he recognized as epoch making-" his piece, De Circul. Sang., which discovery I prefer to that of Columbus." He recogniz ${ }^{2}$ that in the faculty of observatiion the old Greeks were our masters, and that we must return to their methods if progress were to be made. He had a much clearer idea than had sydenham of the value of anatomy, and tells his young friend, Power of Halifax, to make Autopsia his fidus Achates

That he should have believed in witches, and that he should have given evidence in 1664 whlch helped to condemn two poor momen, is always spoken of as a blot on his character; but 8 man must be judged by his times and his surroundings. While regretting his credulity, we must remember how hard it was in the sixteenth and seventeenth centuries not to believe in witches-how hard, indeed, it should be to-day for any one who b lieves implicitly the 0ld Testament!-and men of the stamp of Reginald Scot and Johannes Wierns, who looked at the question from our point of view, were really anomalies, and their strong presentation of the rational side of the problem had really very little influence on their contemporaries.

For you, young men, the writings of Sir Thomas Browne have a very positive value. The charm of high thoughts clad in beautiful Janguage may win some of you to a love of gond literature; but beyond this is a still greater advantage. Like the Flloughts of Marcus Aurelius and the Enehiridion of Spictetus, the Religio is full of counsels of perfection which appeal to the mind of youth, still plastic and an. hardenea by contact with the world. Carefully studied, from such books come subtle influences which give stability to charaeter and help to give a man a sane outiook on the complex problems of life. Sealed early of this tribe of authors, a student takes with him, as compagnons de voyage, life-Iong fiends whose thoughts become his thoughts and whose ways tecome his ways. Mastery of self, conscientious devotion to dutry, deep human interest in human beings-these best of all lessons you must learn now or never; and these are some of the lessons you may glean from the life and from the lips of Sir Thomas. Browne.

REPRRENCE AND NOTE. 1 Wilkin, vol. I. p. 253.2 They did not issue an edition in 1848, as

A Mrmorial to Oblimr.-A statue of Ollier, the famons surgeon of Lyons, has recently been erected in his native place; Vaus, in the Ardeche. It was formally unveiled a fow days ago in the presence of a number of notabilities.

\section{An Adoress}

ox

\section{SCIENTIFIC RESEARCH IN MEDICINE \\ Delivered at the Opening of the London School of \\ Tropical Meducine.}

Bx GeORGe H. F. NU PTALL, M.A., M.D., Pн D., F.R.8.

THAT great benefits to mankind have followed the discoveries of recent years is obvious to all of us, especial'y with regard to the canses and prevention of yellow fever and malaria, and the results already obtained give abundant prumise of the good that may result from like researchrs in the future. Research is a word we hear on all sides to day. It is the enemy of mere authority-that tyrannous.8pirit which has hampered progress and retarded the advance of scinntific medicine for centuries. The spirit of research is restless of restraint; it chafes at limits ; it leads us ever onward to new questionings and new discoveries, and these in turn lead on to further inquiries. The spirit of research has come to stay. with us as long as the hope and the desire of progress in any domain of human knowledge continue to stir the minds of men.

Experimental medicine is responsible for the greatest advances which have been made in our knowledge of the cause, prevention, and cure of disease. These advances have been based on the labours of many workers, exploring often along different lines. Most important discoveries have exerted but a olight direct eff ct at their inception; their full significance has remained hidden, except perhaps to the few and far seeing. Of such discoveries the majority have been made by those engaged in research in the realms of pure science, and rarely by those guided by principles of direct and imm-diate utilit 7 . Pare science is in this respect unselfish; its aim is not prcfit, but truth ; it makes for light rather than gain. Yet it is the forerunner of that applied science which is more obtrusively the servant of man. Its guiding principle is that knowledge must be sought for its own sake, and not primarily for its. possible or probable applications. And experience has shown that new and fruit-bearing knowledge is seldom revealed to those whose sole purpose is merely utilitarian. Problems of the greatest importance to humanity are awaiting their solution at the hands of those who are willing to labour thus unselfishly, to devote themselves to science for the sake of science, and not for that of the materitl serviee which ecience can be made to yield. If we study disease, we must study disease for the sake of knowledge; the scientific spirit must enter into our work. Devotion to the study; getrated b sach motives, is certain to bring its reward, although the reward may not be material. It seems. scarcely necersary to dwell on this before an audirnce composed chiefly of men belonging to the medical profession, which of all professions is the most unselfiwh. All that can be asked is that those who devote themselves to advaneing the gcience of medicine shall bring to their work the same nuble mutives which guide the ideal physician in his effurts to alleviate the sufferings of his fellow men. The spirit of commercialism should be as foreign to the man of science as it is to the physician, for both should be idealists in the best sense of the word. The fruits of their labours may be gathered by others. but none can rob them of the joy of having brought them forth. The "practical man" may not appreciate such ideals, he may deride those who cherish them; but he is ever ready to use the discoverieg of science for his own ends. The reward of the true pioneer does not lie in what is said by "the fool multitude who choose by show"; he seeks only "the wages of going on"; he finds his recompense in delving into the wonderland of Nature with all its. hidden beauties, and thereby forgetting the smallnees that enters into all men's lives. And there is no meanness in the exultation of the esplorer when a new peak rises on his view, of the searcher of the skies "when-a new planet swims into his ken" The joy of the hunter at the kill is felt by the scirntific worker when a fact which has hitherto escaped observation rewards his patient search for truth.

Research has also its joys in the ever-changing picture that it brings before us ; the phenomena we study faseinate through their very elusiveness. We must be prepared for many disappointments and mueh labour loat; we must be ready to give up much of the ald, if we.wish to grasp the now: 
We must grow with our growing knowledge, per ampliora ad altiora. We must emulate the chambered nautilus : Year after year beheld the silent toil That spread his Justrous coil ; Still, as the spiral grew.

Ho left the past year's dwelling for the new. Stole with soft step its shining archway through, Built up its idle door

Stretched in his last found home, and knew the old no more. o. W. Holmes.

We are not all born with instincts fitted for research, but there are many in whom the talent for investigation lies dormant and unused. It should be one of the functions of educational institutions to detect such men, and to lead them on to do the work for which they are adapted, to place the torch within the grasp of hands that are fit to bear it onwards.

ENDOWMENT OF REsearch NEEDED.

All who are +ngaged in teaching and research have met with such men, and often with regret have been forced to see them drift away into other fields of activity, too often from mere lack of means to offer them encouragement. In this country we constantly see men abandon research for practice, though it is all too obvious that, in the interest of science, we cannot afford to lose them. In such cases the distinction attained by research is used bat as a stepping atone to positions which shall secure a means of livelihood. To carry on research successfully a man needs an assured income so that his mind may be at peace with regard to his material wants. How little encouragement is needed to bring forth such men is geen to-day in many parts of the world. I need gcarcely remind you of the devotion to work for its own sake exhibited by such men as Lazear, Myers, Datton, Plehn, and otherg, who have sacrificed their lives in the stady of tropical medicine. These men consciously risked their lives in their devotion to science, they sacrificed themselves for humanity, and there are many who are prepared to follow in their footsteps.

Is it possible that those who are able and willing to help on human progress can continue to ignore the devotion and seifsacrifice which such men are all too ready to render to their fellow men? We should do all in our power to bring the need in this respect before the educated public, in whose mind there still exists no proper understanding of the material conditions that render scievtific research and discovery possible. The average man is scarcely interested in how discoveries $8 \mathrm{re}$ made, provided that they are made; but an appeal to him based on grounds of public henefit may meet with success; and such an appeal is justified by what has been accomplïshed.

The needs of experimental medicine are so great and urgent that every means short of the undignified should be taken to bring the matter forcibly before the public, which in this country does so much for charity, so pitiably little for the advancement of learning. Medical research needs endowment. For those who are willing to devote their lives to research, means of subsistence should be found in the interest of the public giod. In the regrettable absence of State aid we are forced to appeal to the intelligent public, proving again and again that we need help and still more help, and that we are worthy to receive it at their hands. In this appeal all medical men should join.

The wealthy classes of this country would do well to imitate their brethren in America, where, though the State does much more for learning, private beneficence has nevertheless come to the fore in splendid fashion, endowing universities institutes, and labratories in a truly regal manner. It is high time that medical science should become a more favoured object of benevolence in this country.

OUR Laboratories and Thachers.

In an address delivered by my friex d, Professor W. H. Welch of Johns Hopkins University, some nine years ago he said : "At the present day no country, no university, no medical school can hold even a respectable place in the march of education and progress unless it is provided with suitable laboratories for scientific work." Laboratories are the work. shops of those who engage in research, although there are gome in which much routine work is done and original research neglected. Laboratory work alone does not constitnte research. Laboratories should be thoroughly fquipped and guided by men of capacity, by well-trained teachers and investigators who can give their whole time to the work, not by men "deep versed in books and shallow in themselves." The teachers should be men capable of fostering the scientific spirit in medicine and of training the students under them in objective methods. For this purpose the best teachers are unquestionably those who are also investigators, but to fulfil both the functions of teacher and investigator rf.quires so much time that it is almost impossible to perform any other duties. A non-investigator may cram his students $H X$ ellently for such purposes as examinations, but he will not stimulate his men to progress in independent thought and work. To teach science as it should be taught, in properly equipped and organized institutions, is far more expensive in the case of medicine than in that of any other professional echool; and this is the reason why support is so much required : pure science does not pay for the material needs of those who cultivate it.

In former times our needs were fewer, hat it no longer holds true that " what was good enough of old is good enough yet." The result of clinging to the old traditions has brought about an untenable position amongst science teachers in this country. In many of our institutions one man is often espected to perform duties which in more enlightened Germany are allotted to two, three, or even more teachers, each provided at least with a living wage, apart from the neces:ary support given for their laboratories. Most teachers of science in this country receive pittances of which few are snfficient, many totally inadequate. The same holds for many of our laboratories, which remain ill provided with the means of making use of the costly bricks and mortar of which, in acme cases, they are constructed. I know of cases where even university teachers have to sacrifice a large share of their inevfficient salary in carrying on the work of research in their laboratories. It does not suffice to build laboratories; they must also be provided with sufficlent funds and equipment to enable them to become working entities. In brief, we need living laboratories; we must see that the teacher is supported in a manner commeneurate with his functions, and that aid. however modest, is found for such students as show a marked talent for research.

I have cited conditions in Germany as an instance of what is done in a neighbouring conntry by a "paternal Government." A nloser study of these conditions should certaindy tend to ruffle the national pride of an Englishman. Taker single instance with which I am especially familiar-the hygienic laboratories. In May of this year the new Hygienic Institute of the University of Berlin was opened. The building, which containg all modern appliances; was constructed at a cost of $£ 35000$. Ten years ago the Institute received $£ 995$ per annum for current expenses, this year the "Etat" has been brought up to $€ I, 750$ per annum; this apart from the salaries to the teaching body, and apart from grants for special investigations. Every German University and most towns of importance are provided with hygienic institutes, all, as far as practicable, supplied with means adequate to enable them to perform their useful functions. Even in poverty. stricken Italy practically every university is provided with a hygienic institute, which serves, 28 in Germany, as an active centre for research and teaching. Compare this with what is found in this country. There are hygienic laboratories in Edinburgh and Manchester, which may modestly compare with some of the institutions abroad. Take Oxford and Cambridge, our oldest Universities, and we see that no provision exists for research or even proper teaching in hygiene. It stems inconceivable to outsiders that these Universities are poor, and cannot found new institutions, and that there are other and perhaps more pressing needs. All I can say, in the words of a talkative Irish patient I knew, "Poverty is no disgrace, but it is mighty unhandy" and we must continue to hope for better days. We in Cambridge are earnest]y hoping that a helping hand may soon be extended to the relief of a condition which cannot persist.

\section{The London Schoor of Tropicat Mediche and its} STUDRNTS.

Those of us who have watched the progrees of this school from its inception have witnessed a straggle upward which is worthy of all praise and felicitation. This and the sister institution in Liverpool are known throughout the world for the excellent work accomplished by the members of the teaching ataffs and some of the students they have sent forth. Your school has a great mission to fulfil. It has to train man in the methods they will be called on to employ in many parts of the world, and to give them the latest and the best to take with them on their distant journeys. The amount crowded into your courses already shows the rapidly. increasing importance of the subjects treated, and the need, some day in the 
future, of making certain modifications in the plan of study 808 to relieve the increasing burden on the teacher and student.

It is to be hoped that the public will second the noble efforts you have made to establish a centre for the study of the diseases which affect the inhabitants of the tropical countries of this vast empire. You have already made your influence felt throughout the world, for the men trained within these walls are constantly being distributed over the empire, and occupy places where they will continue to transmit the stimulus which radiates from this institution. We are at length beginning to see the dawn of better days, when we ourselves can supply men to solve the great problems which it is our duty to investigate without calling in, as heretofore, the men whom Germany and France have trained and lent us in our helplessness.

How many things by season season'd are

To their right praise and true perfection :

(Merchant of Venice, v. x.)

There is much for us to do before we reach "perfection," and we must continue to strive onward and npward. I should like to see some means devised, for instance in this school, to maintain a form of union between those who have enjoyed the opportunity of studying in its laboratories, to see arise a feeling of corporate attachment between the institution and those who have passed through its portals. This might be accomplished by the publication of a bulletin or the like, which would serve to keep the men in touch with each other and with their teachers after they have left the school. The school, for its part, would surely benefit by fostering the ties which unite it with its former students. The grown-up sons who are out in the world would be encouraged to remember, and on occasion to support and assist, their Alma Mater.

The examination which we have instituted at Cambridge cannot fail to react upon the schools where tropical medicine is taught in the direction of broadening and deepening the tnowledge imparted to those destined to present themselves as candidates. For instance, it has already become obvious to $\mathrm{us}$ that the subjects of tropical hygiene and bacteriology require more attention than they have received at the hands of those desiring to attain to our diploma. It is fully recog nized that there are difficulties in the way of lengthening the curriculum or of increasing the amount of study in the period which is at present allowed for the courses in tropical medicine. Bat it is obvious that some gain might result from a stricter choice of subject-matter. The study of tropical medicine has often been referred to as a special study, but it embraces a very wide range of knowledge, and in practice is constantly spreading into the realm of general medicine. To have a sound knowledge of tropical medicine presupposes as good a knowledge of general medicine. It follows that those who turn to the study of tropical medicine should do so on a basis of sound general knowledge.

The necessity of giving as much practical instruction as possible is obvious to as all in an institation such as this. Men can take books with them to the tropics, but they rely on their practical training for methods. To put a cookery-book in the hands of a woman who cannot ditinguish between pepper and salt would be to court disaster. Instruction in general principles will make it clear that methods are not stereotyped. They are but aids to obtaining a result; they must be varied according to conditions, and new methods must be evolved to meet unexpected difficalties. That is where the untrained man breaks down; in face of a new situation he cannot go beyond his book. If he has not learned in the laboratory how methods are evolved and adapted to particular problems as they arise, he is helpless and barren; he has " no root in himself."

It would be well to sound a warning to young workers as to the value of good methods and thoroughness in work-to counsel patience in research, to emphasize the wisdom of avoiding the tendency to undue haste in publication, and to ridicule the love of publicity and advertisement that has seized upon some of our brethren at home and abroad. These failings discredit not only scientific men but science itself, for they lead to over-hasty and unwarranted generalizations, and to the premature application of discoveries that are but half-born. A carelessly worked-ont contribution to science, even though it be but a maiden effort, often throws discredit on the good work which a man may do in after-years. This damaging result is often risked in the struggle for recognition, but the penalty is sure, for it is at least as difficult to recover a reputation in science as it is in morals. If some seem inclined to deprive others of their dne by lond trumpeting and "pushfulnees," let us not be of them : reputations so achieved have no enduring quality. At the same time, it would be wel if those holding established positions did all in their power to assure just recognition of the work done by younger men. To win the praise of the masters should be the ambition and the attainable reward of the aspirant. Finally, well-trained men, when entrusted with investigations or sent out on expeditions, should not be burdened with too many instructions from committees and the like-composed frequently of wellintentioned gentlemen at home who scarcely understand the conditions at the front. We speak of fair play in sport; let us see that there is more fair play in science.

The Trend of Rechet Invmstiantion.

A survey of recent work in tropical medicine shows us that investigation is chiefly being directed to the study of protozoal diseases. No advances of fandamental importance have been made with regard to malaria since the classical investjgations were published with which the names of Ross and Manson, Grassi, Bignami, and Bastlanelli will ever remain associated. The earlier work has been confirmed and extended by many investigators. The prevention of malaria by means of mosquito destruction and other measures directed against mosquitos has been tried in varions localities, in some instances with success, in others with doubtful results. This is, however, only what might be expected in view of the diversified difficulties which must necessarily arise. Such difficulties must be met and overcome by ripening experience. There has been a veritable flood of malaria literature of recent years, including an annual volume of Attideila Societd per gli studi della Malaria, the series commencing in 19co, which has come to us from Italy. Mosquitos have received an immense amount of attention after being mach neglected in the past. The number of genera and species and their classification have become subjects to bewilder all but specialists.

The important discoveries on sleeping sickness ushered in by the researches of Castellani, a papil of this school, have been confirmed and extended by Brace and his collaborators of the Sleeping Sickness Commission. The relation of the flies belonging to the genus Glossina to the transmission of the trypanosomes is being actively stadied, and many important questions, we must hope, are nearing their solntion in connexion with this most fatal malady. A contribution has just come to hand from Gray and Talloch with regard to the multiplication of the parasites in Glossina, indicating that the belief recently expressed is warranted, namely, that the parasites undergo a cycle of development within the insects. Of importance in their bearing on the question of the development of trypanosomes in other than their vertebrate hosts are the investigations of Schaudinn on Trypanosoma noctuae in Culex, those of Brumpt on certain trypanosomes of fishes which undergo their cycle of development in leeches, and those of Prowazeck on the rat trypanosome which he has demonstrated undergoes development in the rat louse (Haematopinus spinulosus).

Of recent diecoveries, the one which to me appears to carry the greatest weight is that of Novy and McNeal. They have been the first to obtain pure cultures of protozoa, maintrining trypanosomes of different epecies alive in vitro for many generations. There is no telling whither the methods they have given us may lead; they directly stimulated Leonard Rogers to experiments wherein he succeeded, by an ingenious method of his own, in caltivating another protozoon-the Leishmania -obtained from cases of kala-azar.

The work on the tick-transmitted diseases known as the piroplasmoses (redwater, etc.), occurring in cattle, sheep, horses, and dogs, has been pursued in various parts of the world with great activity. The results appear to me to indicate, what I believe also holds for human malaria parasites, that we shall in time learn to distinguish different parasites which we at present consider to represent single species.

Toward the end of last year, the presence of spirochaetes in the blood of persons suffering from tick fever was demonstrated by Philip Ross and Milne in Uganda.

The investigations of Datton and Todd on tick fever in the Congo Free State, announced in February, have given scientific proof that this disease is transmitted by a tick (Ornithodoros moubata) after it has infected itself with blond containing the spirochaeta. This has been confirmed by Koch, if we may rely on what has appeared recently in German newspapers. It is, however, quite premature to assume that African tick fever and European relapsing fever are due to one and the same species of spirochaeta-in fact, it is highly probable that this is not the case, although the report in question refers to the spirochaetae as one species. 
In relapsing fever in Europe the bedbug (Cimex) has long been suspected to be a carrier of the infective agent, a probability which was considerably heightened by Karlinski's observation of motile spirochaetae in the bodies of the insects up to thirty days alter they had fed on relapsing fever blood. Schaudinn, moreover, informs me that he has observed the multiplication of the Spirochaeta obermeieri in Cimex. These observations, following closely upon those published by Marchoux and Salimbeni, are or greatest interest and practical import. The last named authors demonstrated that a fatal disease of the fowl in Brazil is due to a spirochaeta which is transmitted through the agency of a tick (Argas miniatus), and this is capable of conveging the disease even six months after feeding on infected blood. These spirochaetae multiply in the tick, and are present in large quantities in its body cavity throughout this period. These observations are very suggestive since they demonstrate the long parsistence of the parasites in their carriers, and render it probable that they will be found to be harboured much longer.

Finslly, the finding this zear of spirochaeta pallida in syphilis by Schaudinn and others in man, and by Metchnikoff and Roux in experimentally-infected apes, cannot escape a passing notice even though the disease is, unfortunately, not confined to the tropics. It is of some interest to note that the close blood relationship existing between the apes and man, demonstrated independently by means of the precipitins by Grünbaum and myself, served as a direct incentive for the experiments of Metchnikoff and Roux, Lassar, and Neisser, which proved that human syphilis is communicable to the chimpanzee and ourang-outang.

Of interest have also been the further discovery this year of a number of new protozoal parasites in the blood of different animals, in addition to numerous new species of trypanosoma. I refer to new forms called "leucocytozos" because they inhabit the white blood corpuscles of their vertebrate hosts. Leucocytozos were first discovered by Bentley in dogs in India, and were described, without sufficient mention of this fact, by James. Another species bas been found by $A$. Balfour in the rat (M. decumanus) in Khartoum ; and, lastly, W. B. Patton informs me that he has found a species in the squirrel (Sciurus palmarum) in India, and apparently observed developmental forms thereof in a louse. Balfour has, moreover, described a new haemogregarine occurring in the jerboa (Jaculus jaculus), and Graham-Smith, in our laborators, has found another new endoglobular parasite in the mole. This by no means exhausts the "finds" of this year, but it will ouffice to show that British workers are doing their share in furthering our knowledge in this regard.

Of the diseases due to vermes I can say but little. The discovery of Oatto's Schistosomum in this laboratory is familiar to you all. It is interesting to note, following on the experiments with Ankylostoma duodenale by Looss, proving that the embryo worm can infect by penetrating through the skin, that Boycott in London and Tenholt in Germany have confirmed the fact this year in two experiments conducted on medical men who volunteered for the purpose.

Again, it is apparent that the subject of immunity in relation to protozoal diseases is proving to be one of great difficulty, and the results hitherto obtained indicate that new methods will have to be devised if the problem is to be solved from a practical, and still more so from a scientific, standpoint. It is also obvious in this connexion that the problems before us can only be solved by animal experiment, and this accentuates the need of our giving an increasing amount of attention to comparative pathology as we push on toward the alleviation of the ills to which our own flesh is heir.

Gentlemen, I must apologize for the very sketchy nature of the summary which I have jast given you. There are many matters left untouched, including even such important diseases as yellow fever and Malta fever, on which active work has been done. My object has been to seize upon a few salient facts with a view to showing how much has been accomplished within a short period, and how great are the opportunities of the workers in this school who are destined to labour in new fields in different parts of the world. Perhaps what I have said-in no spirit of presumption-will serve as an incentive to some of mv hearers. Let me conclude with some wise words from the Talmud :

The day is sbort and the work is great: It is not incumbent upon thee to complete the work, but thou must not therefore cease from it.
A NEW OPERATION FOR MODERATE SHORT BIGHT.

Br ERNEST E. MADDOX, M.D., F.R.O.8. EDIN., Ophthalmic surgeon, Royal Victoria and Royal Boscombe Hospltals,
Bournemouth.

Having already described in the British Madicat Jourana of October 15th, 1904, p. 1042, an example of the amelioration of short sight by pressure-massage of the eyeball, it may be of interest to communicate the sequel. It is, indeed, more for its interest, as the first of its kind, than as a precedent, that I narrate the operation which follows, since it is of too hazardous a nature to be justifiable except under the exceptional circumstances of this special case. Though very high degrees of myopia have for some years, by nearly all ophthalmic surgeons, been satisfactorily treated by removal of the crystalline lens, no operation for moderate degrees of shor sight has, to the best of my. knowledge, been ever attempted hitherto, much less carried to a successful conclusion. The history briefly is as follows: $X$, aged 16 , while training for Woolwich, was discovered by Dr. Heygate Vernon of Boscombe to be disqualified for the medical examination by a slight excess of short sight in both eyes, but rather more in one than in the other. Owing to family circumstances, the loss and disappointment were so great that Dr. Vernon sent him to me on April 25th, 1904, to see if I could possibly do anything for him. This led me frst to try the pressure-massage treatment recommended by Dr. Domec of Dijon, which improved his vision to the extent described in my former communication, and which would have passed him through the army medical examination with ease, had it been held sooner.

By December, 1904, however, the improvement had disappeared and repetition of the pressure massage was now insufficient to bring his vision to the required standard. This I attributed to the eight montbs of hard study causing aggravation of the defect by further lengthening of the ejeball.

On presenting himself for the army visual examination in January, 1905, one eye was passed, with just is, and the other rejected as s' $^{6}$; and, though appeal was allowed, he failed again. Upon his pleading that I had proposed to do an operation to make the eye pass, he was told that since there was none that could be done, it was quite impossible. Unable, therefore, to get a respite for the parpose, the candidate had to work for two more terms of study, and go over the whole knowledge examination again before he could get a chance to reapply, with all the risk of thereby increasing his myopia."

I therefore took measures to prevent increase of myopia in his better eye, and after fully laying before him the risk, and not withholding the fact that it had never been done before, I pielded to his repeated requests to attempt the operations which I had planned. They consisted in flattening the cornea, first in one meridian and then at right angles, the idea being borrowed from an informal and then untried suggestion which I had made, during a brief communication to the Ophthalmological Society, for the correction of myopic astigmatism by conjunctival sutures. Taking the patient into my nursing home on January 20th, 1905, and without chloroform, I thought it best to commence with the most difficult meridian, namely the horizontal, first, so that should the experiment fail, he might be spared two operations. It is impossible, with most eyes, to make a large lateral corneal incision with a straight cataract knife. I, therefore, first of all dissected up a conjunctival $\mathrm{flap}$, and threw it over the cornea, then introduced a triangular iridectomy knife between the reflected conjunctiva and the sclera, and entered the anterior chamber.

This route I had never traversed before, and it made the operation an exceedingly delicate one, for the peripheral nature of the incision, in his unusually nervous and mobile eye, made the iris prolapse again and again, and especially after enlarging the incision above and below with a probepointed knife, which formed the next stage of the operation, for only a very large incision is capable of producing a regalar flattening of the cornea. At last the iris was comfortably reposed, and the conjunctival sutures inserted so as to exert considerable traction on the flap. Healing was painless and uninterrupted. The second operation was done on April 7 th, after another term of study, and was a much simpler matter than the first. The incision was made with an ordinary cataract knife, this time downwards, and the healing was equally speedy. On August 23rd, after another term of study, he wrote: "I passed the medical successfully yesterday."

* since discovering that the visual 1mprovement by Domec's pressure massage has an evanescent factor, I have (as in the case of another effective, but temporary, measure) not felt justifled in practising it just before army and navy examinations, as it would man'festly defeat the inten- 